\title{
International Politics of the Persian Gulf
}

\author{
Mehran Kamrava \\ New York: Syracuse University Press, 2011. 374 pages.
}

The Persian Gulf region is home to the six members of the Gulf Cooperation Council (viz., Oman, the UAE, Qatar, Bahrain, Kuwait, and Saudi Arabia), Iran, and Iraq. Holding over 60 percent of the world's oil and over 40 percent of its natural gas reserves, the Persian Gulf is central to the global economy. Yet a dominant regional power is lacking; beginning with the British in the late nineteenth century, foreign powers have consistently been meddling in the region. Significant economic, social, cultural, and political changes have transformed the region's international relations since Britain's withdrawal in the 1960s. The contributors to this volume, which provides a rich account of this transformation, focus on natural resources, the Iranian-Saudi competition, the interest of major external actors, and political reform.

The volume's main thrust is the centrality of both state and regime security in order to understand the region. The volume's editor, Mehran Kamrava, notes that the international politics there is essentially that of security politics. He offers four reasons for this: (1) its central role in oil and natural gas production and, increasingly, global finance, (2) the competition between Iran and Saudi Arabia over regional leadership, (3) the long-standing American-Iranian conflict, and (4) the instability brought about by intermixing politics and religion.

He identifies three poles of power that shape the region's security dynamics: the American pole; the GCC pole, which is centered on Saudi military and Qatari-UAE financial power; and the Iranian pole, which relies both on military might and soft power. Since the Iranian revolution, the American and the GCC poles have built a resilient alliance that has been driven by both the United States' growing direct involvement and the GCC's failure to provide security to its members.

The chapters, written by leading regional specialists, further elaborate on the region's security dynamics. In Chapter 2, J. E. Petersen offers a useful typology of boundary formation. He discusses how the state-building process, historical claims, colonial imposition, and resource competition have shaped state boundaries. As these boundaries remain contested, Petersen details various ongoing problems. In Chapter 3, Fred H. Lawson refines the concepts "security dilemma" and "alliances dilemma" and uses them to explain the arms race in the Gulf since the first Gulf War. Middle East specialists and international relations scholars will find these chapters useful in conceptual refinement. 
Regional security arrangements have been on the agenda since the creation of the GCC in 1981. In Chapter 5, Joseph Kostiner argues that the GCC failed to be an effective collective security organization, as evidenced by both the organization's inability to prevent Iraq's invasion of Kuwait and to check Iran's control of the island of Abu Mousa (claimed by the UAE). The GCC remains weak because its members "have still not developed a uniform policy or common institutional framework to address emerging threats" (p. 116).

Persian Gulf security has therefore been internationalized. In Chapter 6, Mohammed Ayoob discusses American foreign and security policy in the region. He argues that the United States has historically relied on a string of regional proxies - Iran, Iraq, and Saudi Arabia - to secure its interests. As these proxies proved unreliable, American policy shifted to assuming direct involvement, meaning an expanded military footprint, thereby providing a sense of security to GCC states and stoking a sense of insecurity in Iran. Ayoob predicts that "the United States is likely to face increasing challenges in the Persian Gulf over the next decade," and suggests that it should take a back seat to the "preeminent regional powers" and increase diplomacy (p. 143).

Steven Wright examines the foreign policies of the region's states. He notes that despite regional unity as regards Islam and culture, security competition has been a key feature of the region's politics. He also argues that although foreign policy decision-making has been the prerogative of a small number of elites, an informal space for political participation exists because traditional tribal and Islamic norms call for consultation (p. 78). The ongoing political reforms, as discussed by Katja Niethammer, are unlikely to expand the political space and allow popular voices to shape foreign policies because "domestic reforms in these states have maintained the ruling elites' dominance in core processes of political decision making, including foreign policy" (p. 234).

A further security dynamic is the competition between Iran and Saudi Arabia for regional dominance. Kamrava examines Iran's foreign policy and argues that its focus has been on security, which is both a product and a factor in "the militarization of the country's immediate environment" (pp. 185-86). He discusses how the Iranian revolution's legacy, the changing political and military environment, the factional competition within Iranian elites, and the institutional framework of the Islamic Republic have all shaped the country's foreign policy. In this context, he argues that Iran has shown remarkable creativity in balancing ideology and pragmatism.

The other regional powerhouse, Saudi Arabia, is discussed by F. Gregory Gause, III. As is the case with Iran, Guase argues that Saudi policy has also focused on maintaining the regime's internal and external security. Saudi Ara- 
bia has been particularly worried when challenged by a powerful external actor, such as Iran, which "directly attacks the domestic legitimacy of the Saudi regime and tries to encourage elements within the Saudi population to oppose the regime" (p. 176). According to Gause, while Saudi Arabia lacks the capability to be a regional hegemon in the broader Middle East, it seeks hegemony in the Arabian Peninsula and leadership in the Gulf, a desire that has been institutionalized by the GCC.

Two other foreign actors play a large role in Gulf politics: India and China. N. Janardhan, who examines their involvement, argues that in addition to historical ties, current economic relations and immigration have brought Asia and the Persian Gulf even closer. This relationship has been economically beneficial to the parties involved: "More than half of the Persian Gulf exports go to Asian countries, while a third of Gulf imports originate in Asia" (p. 211). Although this relationship has not produced a military or political partnership for the Arab Gulf countries, China has built strong military and strategic ties with Iran and Pakistan. In terms of providing oil, Iran has become to China what Saudi Arabia has been to the United States; in return, it has been granted observer status in the Shanghai Cooperation Organization (pp. 227-28).

Overall, the volume is a great contribution to the growing scholarship on the international politics of the Persian Gulf. Yet it suffers from two shortcomings. First, it reduces international politics to inter-state politics. The contributors pay little attention to non-government actors, ideas, interactions, and interests. Saudi Arabia's Shi'ah minority never appears as an actor with agency; relevant book chapters feature the group as merely a proxy for SaudiIranian relations. Al-Jazeera is discussed only to the extent that its reporting complicates Saudi-Qatari relations or extends Qatari soft power; there is no analysis of its independent role in the region's politics. The region's immigrant and expatriate communities merit only a passing reference in the context of India's connection to the region; the larger ways in which these communities influence the region's politics is not discussed. In this framework, neither powerful personalities (e.g., Yusuf al-Qaradawi) nor transnational movements and groups (e.g., the Muslim Brotherhood) have much influence.

Second, the book reduces international politics to security politics. Apart from the discussions of China and India, the region's economic, financial, and commercial relations are excluded. The volume does not address the GCC's economic and financial aspects or the economic relations between the various Persian Gulf countries. Admittedly, states are dominant and security concerns are primary, but this does not mean that the totality of the region's politics can be reduced to these concerns. 
In sum, the volume is a welcome addition to the literature on Persian Gulf politics. It offers a robust view by leading scholars of the region. It could be even stronger if it included more diverse voices and approaches that would capture the variety of actors, institutions, interests, and interactions in the Persian Gulf region.

Turan Kayaoglu Associate Professor of International Relations Associate Director, Interdisciplinary Arts and Sciences University of Washington, Tacoma, Tacoma, WA 